\title{
The Environment as a Factor of Production
}

\author{
Timothy J. Considine and Donald F. Larson
}

\begin{abstract}
This paper develops a model of environmental resource use in production with an empirical analysis of how electric power companies consume and bank sulfur dioxide pollution permits. The model considers emissions, fuels, and labor as variable inputs with quasi-fixed inputs of permits and capital. Incorporating information from permit markets allows us to distinguish between user costs and asset shadow values. Our findings indicate that firms are holding stocks of pollution permits for reasons other than short-term cost savings. The results also reveal substantial substitution possibilities between emissions, permits stocks, and other factors of production. We speculate that anticipated secondary markets for carbon-offset inventories related to the flexibility mechanisms of the Kyoto Protocol will have similar effects for greenhouse-gas emitting firms.
\end{abstract}

World Bank Policy Research Working Paper 3271, April 2004

The Policy Research Working Paper Series disseminates the findings of work in progress to encourage the exchange of ideas about development issues. An objective of the series is to get the findings out quickly, even if the presentations are less than fully polished. The papers carry the names of the authors and should be cited accordingly. The findings, interpretations, and conclusions expressed in this paper are entirely those of the authors. They do not necessarily represent the view of the World Bank, its Executive Directors, or the countries they represent. Policy Research Working Papers are available online at http://econ.worldbank.org.

Timothy J. Considine is a Professor of Natural Resource Economics at Pennsylvania State University; Donald F. Larson is a Senior Economist with the World Bank's Development Research Group. This research was supported by a World Bank research grant and the Gilbert H. White Fellowship Program at Resources for the Future. Shilpa Rao and Nazia Mohammed provided research assistance. Comments from Dallas Burtraw, Graham Davis, Denny Ellerman, Douglas Hale, Karen Palmer, and participants in the Electricity Working Group at the Energy Information Administration and the University of Colorado Workshop on Resource and Environmental Economics are also appreciated with the usual disclaimer. This paper is dedicated to Mr. Carlton Bartels of Cantor Fitzgerald, Inc., who provided data and advice for this study. Mr. Bartels died in the attack on the World Trade Center on September 11, 2001. 


\section{Table of Contents}

I. The Allowance Trading System __ 4

II. Economics of Emissions Permit Banking__ 8

III. The Economic Model __ 11

IV. Econometric Formulation

V. Sample and Estimation Issues __ 19

VI. Empirical Findings__ 22

VII. Conclusions _ 27

References — 28

Appendix $A_{2} 38$ 


\section{List of Tables}

Table 1: Permit allowances held in various accounts in thousands, 1996-2001___ 31

Table 2: Summary statistics for output and input costs per unit of output, 1995-1999___ 31

Table 3: Summary statistics for permit balances in thousand tons ___ 31

Table 4: Summary fit statistics___ 32

Table 5: Parameter estimates from generalized method of moments estimation ___ 33

Table 6: Short-run input demand elasticities with absolute t-statistics in parentheses ___ 34

Table 7: Short-run Morishima elasticities with absolute t-statistics in parentheses ___ 34

Table 8: Long-run input demand elasticities with absolute t-statistics in parentheses ___ 35

Table 9: Long-run Morishima elasticities with absolute t-statistics in parentheses ___ 35 


\section{List of Figures}

Figure 1: Spot and Forward Price Spreads for $\mathrm{SO}_{2}$ pollution permits, 1995-2001 36 Figure 2: Distribution of transactions costs and uncertainty premiums for pollution permit stock holding 37 


\section{The Environment as a Factor of Production}

All economic activity involves either the direct or indirect use of common property environmental resources that are transformed from a natural state to some degraded condition via emissions. Ayers and Kneese (1969) developed the material balance principle to measure this transformation, arguing that material inputs should be defined broadly to include water and air in addition to fuels and conventional material inputs. Van den Bergh (1999) argues that neoclassical production functions are not necessarily inconsistent with mass balances, but empirical models of cost and production often do not provide adequate information to fully understand input substitution possibilities to improve the environment. This study attempts to fill this void by developing a model that includes capital, labor, energy, and material inputs, along with environmental resources as factors of production.

To a considerable extent, firms already consider the environment in their production activities, usually in response to regulation induced by the inefficient allocation of environmental resources arising from market failure. In some cases, governments create markets for permits or allowances to consume these environmental resources more efficiently. With a market for pollution permit allowances, firms equate their marginal costs of abatement, collectively generating an equilibrium market price for permits as they allocate factor inputs to minimize

production costs. In equilibrium, the marginal cost of pollution abatement equals the marginal benefit of avoided environmental damages, consistent with the societal consensus reflected in the statutory permit allocation. Hence, the equilibrium permit price is essentially a price for emissions, which is equivalent to the consumption of environmental resources. 
The permit market for sulfur dioxide $\left(\mathrm{SO}_{2}\right)$ emissions in the United States is often cited as a blueprint for developing markets for allowances to emit greenhouse gases. Under this system, regulators allocate permits to meet an industry-wide emissions target. Though the permit system requires firms to consume a permit for every unit of pollution emitted, firms can adjust their emissions to minimize cost based on the price of permits relative to the marginal cost of reducing emissions. Several studies, including Tietenberg (1990) and Carlson et al. (2000), demonstrate that these trading systems improve efficiency over uniform emissions standards. Firms with relatively high pollution control costs can avoid these expenses by purchasing excess permits generated by firms with relatively lower pollution abatement costs. Profits gained from permit sales provide incentives to substitute inputs or adopt new technology to cut emissions.

Another flexible feature of the U.S. $\mathrm{SO}_{2}$ pollution permit-trading program is that firms can bank emission allowances for future use. Stocks of allowances are likely to be valuable because future regulations, output, emissions, and technology are uncertain, and the penalties are high for emissions that are unmatched with allowances. For example, if a firm underestimates sales, they can use stored pollution permits to increase output. Likewise, uncertainty about the efficiency of pollution control equipment may induce firms to adopt a wait-and-see attitude and to keep a stock of allowances if emission control costs become too high. Additionally, the uncertainty of future regulation of emission levels could motivate firms to bank permits, even if current prices exceed those for future delivery. Stocks of permits, therefore, are assets that generate a flow of benefits over time, much as Ramey (1989) has shown for inventories.

This paper captures the stock and flow dimensions of pollution permit use with a model of U.S. fossil-fuel electric power generation cost that makes the distinction between the short- 
run, when capital and permit stocks are fixed, and the long-run, when all inputs are allowed to vary. Our empirical analysis involves estimation of a short-run restricted cost function that estimates substitution between low and high sulfur fuels, labor and maintenance, and emissions, given these input prices and predetermined levels of output, capital, and permit stocks.

Equilibrium levels of permit stocks and capital are imputed by solving the long-run equilibrium conditions that equate user costs with shadow values. In the short run, the difference between user costs and shadow values may reflect transactions costs, uncertainty premiums, or firm characteristics.

Our model differs from many studies employing marginal abatement cost functions because no strong assumptions about the nature of production and the environment are required, such as strong or weak separability between emissions and other factors of production. ${ }^{1}$ In laying a foundation for econometric analysis, our framework also allows empirical estimation of the determinants of the demand for environmental pollution permits, including output, relative input prices, and non-price induced or biased technical change. As of this writing, there are no other empirical studies employing structural econometric estimation of firm behavior under emissions trading.

The next section of this paper provides a brief background on the $\mathrm{SO}_{2}$ trading program and market performance. Section two of the paper provides a synopsis of recent studies of the economics of emissions banking, providing a basis for the theoretical model developed in section three. The formulation of the econometric model appears in section four. The features of the

\footnotetext{
${ }^{1}$ Obviously, the marginal abatement cost framework was necessary prior to the advent of permit trading.
} 
sample and related econometric issues are discussed in section five. The sixth section presents estimates of short and long-run demand and substitution elasticities of input use, emissions, and permit demand. The paper concludes with a discussion of the policy implications of the findings.

\section{The Allowance Trading System}

Title IV of the 1990 U.S. Clean Air Act Amendments (CAAA) mandates a 10 million ton reduction in $\mathrm{SO}_{2}$ emissions from 1980 emission levels for fossil-fueled-fired power plants. The program involves two phases. Phase I began in 1995 and affected 263 of the dirtiest generating units at 110 mostly coal-burning electric utility plants located in 21 eastern and mid-western states. An additional 182 compensating units later joined Phase I of the program under a provision designed to prevent utilities from reducing generation from Phase I units and increasing generation from other units. Phase II began during 2000, including another 2,000 smaller units, 25 megawatts or greater, and all new generating units.

Under both phases, owners of regulated generation units are given a fixed number of tradable permits or allowances by the U.S. Environmental Protection Agency (EPA), which administers the program, based upon historic fuel use and emissions, among other factors. At the end of each calendar year, operators of generating units are required to return an amount of allowances to the EPA equivalent to their emissions. A participant's failure to turn in sufficient allowances results in significant financial penalties and more stringent emission standards. ${ }^{2} \mathrm{After}$

\footnotetext{
2 Accurate accounting of $\mathrm{SO}_{2}$ emissions from affected boilers and turbines is an integral part of the Acid Rain Program. Concentrations of emitted $\mathrm{SO}_{2}$ from each unit (boiler or turbine) are measured and recorded using Continuous Emissions Monitoring Systems certified by EPA that directly measure $\mathrm{SO}_{2}$ concentrations from stack emissions.
} 
reconciling emissions with allowances, the EPA issues new allowances for the next year. The EPA maintains a computerized database called the Allowance Tracking System (ATS) that allows owners of affected units, as well as the EPA and third parties, to track the number of allowances in each unit's account. ${ }^{3}$

Permit allocations have departed significantly from any simple rules based upon emissions per unit of production. The study by Ellerman et al. (2000) finds that allocations partly reflect political maneuvering to protect a variety of constituents, particularly coal mining companies and unions. There exists a rather arcane classification of generating units that includes three major categories: Table A, Substitution, and Compensating. The first category refers to all generating units required to reduce emissions under Phase I that are listed in "Table A" in Title IV of the CAAA. Operators of these units were awarded bonus allowances if they installed fluegas desulfurization units, known as scrubbers. Indeed, there were a few scrubber installations during late 1994 and early 1995 but a much smaller number installed between 1996 and 1999. The second category includes generating units that fall under a provision that allows utilities to substitute any other units for those designated under Table A. Compensating units arise under the Title IV provision that allows operators to reduce generation below baseline levels by designating some other unit as a compensating one. ${ }^{4}$

\footnotetext{
${ }^{3}$ The ATS provides the allowance market with a record of the identity of the permit holder and the date and the number of allowances transferred. The ATS does not, however, record the price or other terms associated with allowance trades. Submitting allowance transfers to EPA is voluntary and the unit is not required to report a transaction until it actually uses the allowances.

${ }^{4}$ There are also a very small number of industrial boilers that are allowed to "opt-in" Title IV.
} 
An overview of permit holding in these categories and others appears in Table 1. The reported permit stocks in Table 1 are observed for specific dates when EPA reconciles emissions with allowances. Banked allowances - equal to total allowances held less emissions, steadily increased during Phase I from more than 3.4 million in 1996 to more than 9.6 million during 1999 with a majority of permits held for Table A units. Once Phase II began in 2000, the permit bank declined, reflected in the March 2001 redemption of permits for emissions during 2000 (see Table 1). The sharp increase in allocations during 1996, again reflected in 1997 (see Table 1), may reflect the idiosyncratic nature of allocations in early years due to special provisions under Title IV. These anomalies suggest that permit stock holding, particularly at the firm level, may reflect a number of institutional factors in addition to economic incentives.

Firms or speculators can purchase permits during EPA auctions for a small number of allowances. The intent of the auctions is to ensure that new units have an allowance source beyond the initial allocation to existing units. Another motivation for holding the auctions was to facilitate price determination during the early stages of the program. Since then, however, the $\mathrm{SO}_{2}$ permit market has rapidly evolved with a sophisticated trading network.

Private trading of permits between electric utilities and/or utilities and brokers is the principal mechanism of price discovery. Prior to 1993, the market largely consisted of bilateral trades usually without brokers or with brokers operating similar to investment bankers. Cantor Fitzgerald established a commodity spot market for allowances in 1993, leading to a more than 50 percent increase in intra-utility trading by the end of Phase I. As of March 2000, about 75 million allowances were traded through private transactions, constituting more than half the cumulative trading volume in the market at that time (Bartels, 1997). In addition to Cantor 
Fitzgerald, Emissions Exchange Corporation (EX) and Evolution Markets also publish allowance prices on bids to buy and offers to sell for current vintages of permits, with an average of these bids defined as the spot market price for allowances. Also listed by these brokerages are the immediate settlement prices of allowances for future vintages. A vintage year $\mathrm{t}+\mathrm{T}$ allowance is unusable until year $\mathrm{t}+\mathrm{T}$. Thus, immediate settlement transactions in year $\mathrm{t}$ involving allowances with vintage greater than the current year can be thought of as a $\mathrm{T}$ year forward contract with the date of settlement being the vintage year. Price, quantity, and settlement date (today) are agreed upon by the two parties. Transfer of allowances and money occur at the date of sale. The price on these transactions is essentially a discounted forward price (Bartels, 1997).

A plot of spot prices and forward price spreads for $\mathrm{SO}_{2}$ allowances appears in Figure 1 . Notice that spread between forward and spot prices is often negative or backwardated. The marginal cost of abating a ton of $\mathrm{SO}_{2}$ from the utility sector was initially estimated at $\$ 400$ 1000/ton prior to passage of the Clean Air Act Amendments. During 2000, however, $\mathrm{SO}_{2}$ allowances ranged in price from $\$ 130 /$ ton to $\$ 155 /$ ton (see Figure 1). Some market observers believe lower than expected allowances prices during the early years of the program were due primarily to lower than expected compliance costs and larger than expected emissions reductions, which have increased the supply of allowances and put downward pressure on prices. Ellerman and Montero (1998) perform an econometric analysis of the pre-CAAA period and conclude that lower delivered price for low-sulfur coal due in part to economies of scale in rail transportation caused the total and marginal cost of compliance curves to shift downwards, thereby causing lower than expected allowance prices. 
By several measures, the $\mathrm{SO}_{2}$ trading program has been successful. Schmalensee, et al. (1998) report that during the first five years of the program, emissions declined substantially, driven in large part by a switch to low-sulfur coal from the Powder River Basin in Wyoming. During 1995 and 1996, emissions were 39 and 33 percent, respectively, below allowances issues in those years.

The characteristic feature of a cap and trade program is the immense flexibility in compliance that it offers. Electric utilities under the CAAA program face an array of choices to comply with EPA regulations. Some of the options available include fuel-switching, fuelblending, installation of scrubbers, allowance trading, reducing/switching generation at the units, retrofitting the unit, producing less output, and shutting down inefficient units. The incidence of scrubbing among Phase I units has increased very little since 1996. There are many reasons for this, including high capital costs of scrubbers, prevalence of long-term fuel contracts, and decreasing prices of midwestern low-sulfur coal. Fuel blending and switching and allowance purchases represent the majority of the compliance methods. The exact delineation of these two methods is somewhat complicated as many units choose a mixture of both depending the balance between fuel constraints and allowance prices. While the model estimated below abstracts from these details, it provides insights into their relative importance by measuring factor substitution elasticities.

\section{Economics of Emissions Permit Banking}

Another source of flexibility is permit banking, which allows firms to shift emissions over time. Many studies examine gains achieved from emissions trading between firms and from emissions averaging between sources within a firm, but relatively few focus on the economics of 
emissions trading for the firm. Rubin (1996) develops a continuous-time model of emissions trading, permit banking, and borrowing. He shows that trading results in an efficient allocation of permits that collectively minimizes cost. When permit stocks are positive and the nonnegativity constraint on permits is not binding, the rate of change in the price of emissions follows a simple Hotelling rule, rising at the rate of interest. When the non-negativity constraint is binding, the shadow value of permit stocks is positive and marginal abatement costs rise at a rate less than the rate of interest. Using a similar model, Cronshaw and Kruse (1996) find that abatement costs may not be minimized if firms are subject to profit regulation because permit sales and purchases are treated differently for rate-making purposes.

Kling and Rubin (1997) use an optimal control framework to model permit banking decisions under perfect foresight. They find that, in equilibrium, marginal abatement costs equal permit prices and that permit price growth over time follows Hotelling's rule. They differentiate these conditions with respect to time and develop equilibrium paths for emissions and production that are functions of second derivatives of the cost function, which depends upon output, emissions, and disembodied technological change. Firms have incentives to bank permits when marginal abatement costs are rising, marginal production costs are falling, emission standards are increasing, or output prices are rising. They find that in many cases firms sub-optimally overproduce and pollute in early periods because firms, in their view, consider the stock of permits as a fixed endowment.

Schennach (1999) examines emissions banking under uncertainty. In her model, riskneutral managers of generating units minimize expected discounted cost. If the stock of permits 
is expected to be zero, then the rate of change in marginal abatement costs could be less than the rate of interest. Her equilibrium condition is as follows

$$
E_{t}\left(\dot{m}_{t}\right)=E_{t}\left[\mu m_{t}-\lambda_{t}\right]
$$

where $\dot{m}_{t}$ represents the rate of change in marginal abatement costs in period $t, \mu=r+\rho$ is the discount rate that includes a risk-free interest rate, $r$, and an asset specific risk-premium, $\rho$, and $\lambda_{t}$ is the shadow value on the non-negativity constraint on stocks,. The mere possibility of a permit stock-out, which implies $E_{t}\left[\lambda_{t}\right]>0$, suggests that the expected change in marginal abatement costs could be negative. If permit prices equal marginal abatement costs, the possibility of stock-outs would partially explain permit price backwardations when prices for permits this period exceed those for future periods. Bailey (1998) argues that a convenience yield from holding permits and transactions costs (Stavins, 1995) also contribute to permit price backwardations.

Schennach's stochastic shadow value also would reflect uncertainty surrounding future pollution control costs, market conditions, and regulation. One of the main sources of uncertainty has been the transition between Phase I and Phase II of the Acid Rain Program. Many firms chose to include units that are not subject to Phase I regulations, under the voluntary provisions of the program. Under the EPA's New Source Review ${ }^{5}$, utilities could have been forced to scrub close to $40 \mathrm{GW}$ of coal capacity. This reduction would have freed up allowances and created a glut of permits in the $\mathrm{SO}_{2}$ market. Other regulatory uncertainties include the new national

\footnotetext{
${ }^{5}$ A pre-construction permitting program for large industrial units
} 
ambient air quality standards for ground-level ozone and bills in Congress that propose reducing the national $\mathrm{SO}_{2}$ cap by $50 \%$.

There are only a few empirical studies of $\mathrm{SO}_{2}$ emissions permit banking and none involve structural econometric estimation. Rubin and Kling (1993) use an econometrically-estimated marginal abatement cost function to simulate the cost savings from emissions banking for lightduty vehicle emission controls. Keohane (2001) focuses on the role of environmental policy instruments, including permits on the choice of pollution control techniques. He finds that coalfired electric generating units were more responsive to abatement costs than units under an emissions rate standard. Long-term coal contracts, regional effects, and utility ownership also had significant effects on the choice of abatement techniques, such as the installation of coal scrubbers or the switching or blending of coals to reduce sulfur content and emissions.

Arimura (2001) uses a probit model to explain the choice by plant managers to obtain additional allowances or to switch to or blend low-sulfur coal. His results show that cost recovery rules promoted high sulfur coal use for utilities located in coal producing states. Local coal industry protection increased high sulfur coal use by $50 \%$. Arimura's (2001) findings also suggest that public utility commission regulations also forced utilities to fuel switching and blending, which contributed to unexpectedly low allowance prices during the early stages of Phase I.

\section{The Economic Model}

Carlson, et al. (2000) estimate a translog cost function for electric power generation to estimate the gains from permit trading. Their model involves minimization of labor, capital, and high and low sulfur coal costs subject to demand and emissions constraints. Their cost function 
depends upon prices for labor and capital, prices for low and high sulfur coal, levels of output and emissions, and a time trend to account for technological change. They estimate a fourequation model including the translog cost function, share equations for labor and capital, and an equation for emissions, which yields estimates of marginal abatement costs. They use their model to argue that technological changes and the flexibility to take advantage of low sulfur coal prices are the main reasons for lower marginal abatement costs rather than trading gains per se. The economic model developed below is inspired by Carlson, et al. (2000) with two important differences: emissions are a variable input and permit stocks are a quasi-fixed factor of production.

Ayres and Kneese (1969) showed that the amount of environmental pollutants should approximately equal the weight of energy and raw materials inputs, which would include minerals, water, air, and other common property resources. This mass balance approach, further developed by Ayers (1978) and Ayers (1999), suggests the following production function for electric power generation:

$$
Y=f(F, L, E, K)
$$

where $Y$ is output, $F$ is fuel inputs, $L$ is labor and maintenance, $K$ is capital services, and $E$ represents environmental inputs, such as air, water, and other common property resources. Dual to this production function is a cost function:

$$
C=g\left(w_{f}, w_{l}, w_{e}, w_{k} \mid Y\right),
$$

where $C$ is the cost of producing output $Y$, and the $w$ 's are prices of the four factors of production. In most cases, prices for environmental inputs are unavailable absent trading of marketable pollution permit allowances. If these input prices are available, then this analysis 
suggests that one could estimate a cost function considering the consumption of environmental resources, which is equivalent to emissions, as a variable factor of production. ${ }^{6}$ Under competitive market conditions, the market-clearing price for pollution permits would serve as a good proxy for the marginal emissions factor cost. Given the assumption of a twice continuously differentiable cost function, the demand for emissions is equal to the first partial derivative of cost with respect to the permit price.

Another dimension of pollution permits is storability for future use. Hence, the bank of tradable permits is an asset. In this case, the short run is defined as a time period when the stock of banked permits is fixed. The long run is simply when permit and capital stocks vary. To understand the stock and flow dimensions of permits, consider the following profit function for a firm:

$$
\max _{w, B, K} \Pi_{t}=P_{t} Y_{t}+w_{e t}\left(A_{t}+B_{t-1}\right)-G\left(w_{f t}, w_{l t}, w_{e t} \mid Y_{t}, K_{t}, B_{t}\right)-w_{e t} Q_{t}-\mu_{b t} B_{t}-\mu_{k t} K_{t},
$$

subject to:

$$
B_{t}=B_{t-1}+A_{t}+Q_{t}-E_{t},
$$

where $P_{t}$ is output price in period $\mathrm{t}, A_{t}$ is the allotment of permits given to the firm by the regulator, $G$ is a short run restricted cost function with three variable input categories - fuel, labor, and environmental resources, and two quasi-fixed factor inputs, capital $-K_{t}$ and the allowances banked by the firm at the end of period $\mathrm{t}, B_{t} ; Q_{t}$ represents net permit purchases, $\mu_{k}$ is

\footnotetext{
${ }^{6}$ While a market has emerged in recent years for nitrogen oxide permits, only the $\mathrm{SO}_{2}$ market provides a continuous time series on prices over the sample period. Prices for other by-products of power production, such as carbon dioxide, mercury, and solid wastes are unavailable.
} 
the user cost of capital, and $\mu_{b}$ is the user cost of holding banked permits. Ending stocks of pollution permits by definition equal carryover stocks from the previous period plus the annual allocation granted by regulators plus net purchases less emissions. Note that permit purchases, $Q_{t}$, is positive if firms are net buyers and negative if net sellers.

Assuming output is predetermined, minimizing cost provides a solution to the above profit maximization problem with cost minimizing variable factor input levels given by Shephard's lemma. The short-run demand functions for fuel, labor and maintenance, and emissions are given by:

$$
Q_{i t}=\frac{\partial G_{t}}{\partial w_{i t}}, \text { where } i=f, l, e .
$$

The long-run envelop-conditions for the bank of pollution permit allowances and capital are as follows:

$$
\begin{gathered}
\frac{\partial \Pi_{t}}{\partial B_{t}}=-\frac{\partial G_{t}}{\partial B_{t}}+\mu_{b t}=0 \Rightarrow \mu_{b t}=-\frac{\partial G_{t}}{\partial B_{t}} \\
\frac{\partial \Pi_{t}}{\partial K_{t}}=-\frac{\partial G_{t}}{\partial K_{t}}+\mu_{k t}=0 \Rightarrow \mu_{k t}=-\frac{\partial G_{t}}{\partial K_{t}} .
\end{gathered}
$$

With predetermined permit allocations and carryover permit stocks, the model can be solved for permit purchases from the variable emissions demand function and the condition for ending stocks of permits.

The user cost of capital is defined as the price of new generation capacity multiplied by the real rate of return, which is an asset-weighted average of bond and equity rates less the rate of inflation. The user cost of permits is defined as follows:

$$
\mu_{b t}=r_{t} P_{e t}-\left[P_{e t}^{f}-P_{e t}\right]
$$


where $r_{t}$ is real rate of return on capital, $P_{e t}$ is the price of permits at the end of period t, and $P_{e t}^{f}$ is the forward price of permits for period $t+1$ and beyond in period $t .^{7}$ Unlike capital, a dynamic user cost is adopted for permits because firms can sell and buy back permits at much lower transactions costs. Hence, the user cost of holding permits includes the financial opportunity cost of holding of permits net of the expected capital gain (loss) earned on permit holdings. This specification of user costs together with the condition (7) for permit stocks is consistent with the futures market arbitrage condition described by Brealey and Myers (2003) in which futures prices net of transactions costs reflect the future value of spot prices and the convenience yield from holding permit stocks:

$$
P_{e t}^{f}=\left(1+r_{t}\right) P_{e t}+\frac{\partial G_{t}}{\partial B_{t}}
$$

where the last partial derivative corresponds with the convenience yield from holding permits. ${ }^{8}$

In the short run, however, these envelope conditions may not hold for a variety of reasons. For capital, rate of return regulations may drive a wedge between user cost and the shadow value of capital. Adjustment costs, discussed by Morrison (1988), are another reason for short-run disequilibrium in capital stocks. A similar disequilibrium is also possible for pollution permit stocks due to transactions costs and uncertainty. The following section describes a method for modeling these disequilibrium effects by firm.

\footnotetext{
7 Prices in the permit user costs are measured when EPA reconciles the permit accounts in either January or March of each year. The price for emissions used in the variable input demand functions is an annual average. In addition, the real rate of return contains an implicit risk premium, which is reflected in equity and bond rates of return and consistent with Schennach's model (1999).

${ }^{8}$ Futures prices are often very close to forward prices where the former are marked to market.
} 


\section{Econometric Formulation}

The Generalized Leontief (GL) function developed by Morrison (1988) is best suited for this particular problem because Caves and Christensen (1980) found it more likely to maintain cost minimizing curvature conditions under limited input substitution possibilities, which is a reasonable prior assumption for electric power generation. Another important reason is that the GL provides a closed-form solution for stocks of quasi-fixed factors, which facilities computation of long-run elasticities. For this particular problem, the GL takes the following form:

$$
\begin{aligned}
G_{t} & =Y_{t}\left\{\begin{array}{l}
\sum_{i=1}^{4} \sum_{j=1}^{4} \alpha_{i j}\left(w_{i t} w_{j t}\right)^{1 / 2}+\sum_{i=1}^{4} \delta_{i y} w_{i t} Y_{t}^{1 / 2}+\sum_{i=1}^{4} \delta_{i z} w_{i t} Z_{t}^{1 / 2} \\
+\sum_{i=1}^{4} w_{i t}\left(\gamma_{y y} Y+2 \gamma_{y z} Y_{t}^{1 / 2} Z_{t}^{1 / 2}+\gamma_{z z} Z\right)+\sum_{i=1}^{4} w_{i t} \varepsilon_{i t}
\end{array}\right\} \\
& +Y_{t}^{1 / 2}\left\{\begin{array}{l}
\sum_{i=1}^{4} \delta_{i k} w_{i i} K_{t}^{1 / 2}+\sum_{i=1}^{4} \delta_{i b} w_{i t} B_{t}^{1 / 2} \\
+\sum_{i=1}^{4} w_{i t}\left(\gamma_{y k} Y_{t}^{1 / 2} K_{t}^{1 / 2}+\gamma_{y b} Y_{t}^{1 / 2} B_{t}^{1 / 2}+\gamma_{z k} Z_{t}^{1 / 2} K_{t}^{1 / 2}+\gamma_{z b} Z_{t}^{1 / 2} B_{t}^{1 / 2}\right)
\end{array}\right\} \\
& +\sum_{i=1}^{4} w_{i t}\left(\gamma_{k k} K_{t}+2 \gamma_{k b} K_{t}^{1 / 2} B_{t}^{1 / 2}+\gamma_{b b} B_{t}\right)+K_{t} \varepsilon_{k t}+B_{t} \varepsilon_{b t},
\end{aligned}
$$

where the $\alpha^{\prime} s, \delta^{\prime} s$ and $\gamma^{\prime} s$ are unknown parameters, the $\varepsilon_{i t}, \varepsilon_{k t}$, and $\varepsilon_{b t}$ are stochastic errors, and $Z_{t}$ is a time trend representing biased technological change. The empirical model includes four variable inputs: low sulfur fuel, high sulfur fuel, labor and maintenance, and emissions. The asymmetric way that output and technological change enter the cost function facilitates parametric testing of long-run constant returns to scale. Taking partial derivatives with respect to factor prices provides the following input demand functions: 


$$
\begin{aligned}
\frac{x_{i t}}{Y_{t}} & =\sum_{j=1}^{4} \alpha_{i j}\left(\frac{w_{j t}}{w_{i t}}\right)^{1 / 2}+\delta_{i y} Y_{t}^{1 / 2}+\delta_{i z} Z_{t}^{1 / 2}+\gamma_{y y} Y_{t}+2 \gamma_{y z} Y_{t}^{1 / 2} Z_{t}^{1 / 2}+\gamma_{z z} Z_{t} \\
& +\delta_{i k}\left(\frac{K_{t}}{Y_{t}}\right)^{1 / 2}+\delta_{i b}\left(\frac{B_{t}}{Y_{t}}\right)^{1 / 2}+\gamma_{y k} K_{t}^{1 / 2}+\gamma_{y b} B_{t}^{1 / 2}+\gamma_{z k}\left(\frac{Z_{t} K_{t}}{Y_{t}}\right)^{1 / 2}+\gamma_{z b}\left(\frac{Z_{t} B_{t}}{Y_{t}}\right)^{1 / 2} . \\
& +\gamma_{k k}\left(\frac{K_{t}}{Y_{t}}\right)+2 \gamma_{k b}\left[\frac{\left(K_{t} B_{t}\right)^{1 / 2}}{Y_{t}}\right]+\gamma_{b b}\left(\frac{B_{t}}{Y_{t}}\right)+\varepsilon_{i t}
\end{aligned}
$$

The envelope condition provides an expression that equates the marginal user cost of holding permits with the shadow value of permits:

$$
\begin{gathered}
\mu_{b t}=-\frac{1}{2} \sum_{i=1}^{4} \delta_{i b} w_{i t}\left(\frac{Y_{t}}{B_{t}}\right)^{1 / 2}-\frac{1}{2} \gamma_{y b} \sum_{i=1}^{4} w_{i t}\left(\frac{Y_{t}}{B_{t}^{1 / 2}}\right)-\frac{1}{2} \gamma_{z b} \sum_{i=1}^{4} w_{i t}\left(\frac{Y_{t} Z_{t}}{B_{t}}\right)^{1 / 2} . \\
-\gamma_{b b} \sum_{i=1}^{4} w_{i t}-\gamma_{k b} \sum_{i=1}^{4} w_{i t}\left(\frac{K_{t}}{B_{t}}\right)^{1 / 2}+\varepsilon_{b t}
\end{gathered}
$$

A similar equation exists for capital:

$$
\begin{gathered}
\mu_{k t}=-\frac{1}{2} \sum_{i=1}^{4} \delta_{i k} w_{i t}\left(\frac{Y_{t}}{K_{t}}\right)^{1 / 2}-\frac{1}{2} \gamma_{y k} \sum_{i=1}^{4} w_{i t}\left(\frac{Y_{t}}{K_{t}^{1 / 2}}\right)-\frac{1}{2} \gamma_{z k} \sum_{i=1}^{4} w_{i t}\left(\frac{Y_{t} Z_{t}}{K_{t}}\right)^{1 / 2} . \\
-\gamma_{k k} \sum_{i=1}^{4} w_{i t}-\gamma_{k b} \sum_{i=1}^{4} w_{i t}\left(\frac{B_{t}}{K_{t}}\right)^{1 / 2}+\varepsilon_{k t}
\end{gathered}
$$

The full model then includes four short-run demand equations and two quasi-fixed factor equations, one for permit stocks and the other for capital.

Since utilities are the agents making decisions about allowance use, aggregate data at the operating-utility or holding company level best illustrates banking behavior (Ellerman, et al, 2000). For our panel data set, we assume the following fixed effects for the error terms:

$$
\begin{aligned}
& \varepsilon_{i j t}=\delta_{i j}+v_{j t} \quad \forall i=l s, h s, l, e ; j=1, \ldots, n ; t=1, \ldots, T \\
& \varepsilon_{b j t}=\delta_{b j}+v_{b t} \quad \forall j=1, \ldots, n ; t=1, \ldots, T \\
& \varepsilon_{k j t}=\delta_{k j}+v_{k t} \quad \forall j=1, \ldots, n ; t=1, \ldots, T,
\end{aligned}
$$


where $i$ denotes the variable input, $j$ is the firm, $t$ is the time period, input $l s$ denotes low sulfur fuel, $h s$ indicates high sulfur fuel, the $\delta$ 's are fixed firm effects, and the $v$ 's are random errors.

Given that the envelope conditions for quasi-fixed factors do not include intercept terms, the fixed effects in these equations represent a wedge between user costs and shadow values. Rate of return regulation is a likely reason for divergence between the user cost and shadow value of capital. The fixed effect in the permit stock equation essentially measures the departure of each firm's marginal valuation of stocks from the market returns to storage. There may be many reasons for these departures, including diverse regulatory policies, transactions costs, or the uncertainty premium identified by Schennach (1999). Another reason could involve option values from holding stocks of pollution permits to avoid severe financial penalties from not having enough permits on hand to cover emissions at the end of the year or from banking permits to smooth production or cost in future years in response to tighter emission controls or regulatory and market uncertainty.

For pollution permit stock holding during Phase I of the acid rain program, it is likely that the uncertainty premium varied over time. At the start of Phase I, many companies simply did not know how successful the program would be and, therefore, did not have complete knowledge of the desired stock of permits. As Phase II approached and the success of fuel switching, lower sulfur scrubbing costs, and other measures to satisfy the emission requirements became evident, the degree of uncertainty diminished. This suggests that the uncertainty premium during Phase I diminished over time. To test this hypothesis, the fixed effect in the permit stock equations is amended to include a term that is a function of the years to Phase II. Accordingly, the permit stock condition becomes: 


$$
\mu_{b t}=-\frac{\partial G_{t}}{\partial B_{t}}+\delta_{b j}-\phi\left(T_{\text {Phase II }}-T_{t}\right),
$$

where $\mathrm{T}$ is the year in either the start of Phase II $\left(T_{\text {Phase II }}=1999\right)$, or year $\mathrm{t}$. The last two terms in (15) represent the net transactions cost and uncertainty premium for firm $\mathrm{j}$. The expectation is that $\phi>0$ so that as uncertainty diminishes during Phase I, the disequilibrium wedge gets smaller. The full model includes six equations given by (12), (13), and (15) estimated using observations on costs, output, and factor prices for a sample of firms operating under Phase I.

\section{Sample and Estimation Issues}

The sample consists of a panel of 36 utilities from 1995 to 1999, which is Phase I of the acid rain program. The original sample included 38 firms but two were eliminated due to inconsistencies and errors in the data. A list of the holding companies and subsidiaries used in the sample appears in Appendix A. Following the study by Christensen and Green (1976), firms include holding companies rather than the separate member companies because decision-making occurs at the holding-company level. The companies include very large power systems, such American Electric Power and Southern Company, to small utilities in the Midwest and Northeast.

The primary source of data for this study is the Financial Statistics of Major U. S. Investor-Owned Electric Utilities, EIA Form 1 (Financial Statistics) published by the Energy Information Administration (EIA) and the Federal Regulatory Commission. We also used data on generation and consumption of fuels at power plants (EIA Form 759) and cost and quality of fuels at electric power plants (EIA Form 423). Deregulated companies are not required to file a Form 1. Moreover, for those companies in the process of selling generation plants, large discrete 
reductions in cost and output are observed during 1998 and 1999. As a result, nine observations for companies identified in Appendix A are removed from the sample. ${ }^{9}$ Form 423 data are used to classify fuels into two categories, low and high sulfur fuels, with a cutoff of $0.4 \mathrm{lbs}$ of sulfur per million Btu.

Summary statistics for output and input costs are presented in Table 2. On average, output is 22.4 million megawatt hours with a substantial standard deviation due to the inclusion of Southern Company and American Electric Power. Fuel costs average 1.5 cents per kilowatt hour (see Table 2). High sulfur fuel dominates fuel costs for these Phase I firms. Labor and maintenance costs are the next largest variable input. Emissions costs are miniscule, although like the other cost components: there is a large dispersion with a maximum value of 0.39 cents per kilowatt. Like emissions, permit holding costs - which are the product of user costs and permit stock levels, are a small fraction of total costs. Total costs, including permit and capital costs, average slightly over 3 cents per kilowatt hour.

The data on unit emissions and permit stock holding by firm were collected from the Allowance Tracking System, aggregated from the generation unit level up to the plant and eventually firm level. Summary statistics for the permit balances are presented in Table 3. On average, firms held permits equivalent to 79,000 tons of emissions at $\$ 150$ per ton $-\$ 11.8$ million. Average permit allocations from EPA were somewhat more than double permit stock levels (see Table 3). Net purchases, calculated using equation (5), are negative indicating that

\footnotetext{
${ }^{9}$ Including these observations either caused convergence problems or resulted in large swings in the estimated coefficients.
} 
firms on average were net sellers of permits during Phase I of the program. Presumably, firms sold these permits to speculators other than the Phase I firms.

There are several estimation issues that arise with this model. First, permit stocks are clearly endogenous given (5). Output and input prices, particularly high sulfur fuel prices, also may be endogenous. Several firms, particularly the large ones, are major buyers of high sulfur coal and, thus, could influence market prices through their purchasing patterns and contracting strategies. Moreover, firms may adjust output in response to pollution permit policies. So an instrumental variable estimator is required. According to Shea (1993), selection of instruments should be made on the basis of correlation with the right-hand side variables and on whether the instruments are exogenous with the explanatory variables in the model, which include relative prices, beginning capital stocks, output, trend, and ending stocks of allowances. A good instrument for ending permit stocks is allocations with a simple correlation of 0.74 . Lagged relative prices, lagged output, and a dummy variable for deregulation are used as the other instrumental variables. Using the information compiled by Lile and Burtraw (1998), two additional instrumental variables were created, one for the presence of high sulfur coal deposits for utilities operating in each state and another for the presence of automatic pass-through and incentive-based sharing of allowance costs. The last instrumental variable is the number of years before Phase II. The other estimation issue involves inefficiency introduced from the possible presence of heteroscedasticity, which is likely given the large dispersion in output and levels of quasi-fixed factors. As a result, the estimates reported below use the generalized method of moments, which is an asympototically efficient, instrumental variables estimator. 


\section{Empirical Findings}

With relatively short time series, the trend terms and output are highly correlated, which prevents identifying the separate effects of returns to scale and non-neutral technological change on cost and input substitution. Most previous studies of electric power generation reject constant returns to scale, generally finding increasing returns. Accordingly, the subsequent analysis allows variable returns to scale and compares two models, the unconstrained model and the model with neutral technological change.

The product of the objective function and the number of observations provides a test of the over-identifying conditions of the model. For the unconstrained model, the test statistic is 96.3 with a probability value of 23.8 percent. This test suggests that the over-identifying restrictions cannot be rejected. Using the same set of instruments, the test statistic for the model with neutral technical change is 96.0 with a probability value of 44.3 . The difference between these two statistics is 0.3 with a probability value of 99 percent. Hence, the hypothesis of neutral technological change cannot be rejected. ${ }^{10}$

Based upon these results, neutral technological change is adopted as a maintained hypothesis. In this case, the model is re-estimated with the instrumental variables excluding those involving trend. For this model, the test statistic for the overidentifying restrictions is 73.5 with a probability value of 46.1 percent, which suggests that these restrictions cannot be rejected. The summary fit statistics appears in Table 4. With the exception of the permit stock equation, the correlations between the predicted and actual dependent variables are quite high. Moreover,

\footnotetext{
10 This finding is robust across a range of different model specifications.
} 
the Durbin-Watson statistics and the probability levels indicate a relatively good chance that errors in most of the equations are uncorrelated with their adjacent values in each panel.

All own-price elasticities of demand are negative and the concavity and convexity conditions are satisfied at the sample mean. The shadow value on capital is negative with a probability value of 7.1 percent. The partial derivative of cost with respect to permit stocks is 1.8 , which is only 1.4 percent of the $\$ 132$ average permit price over the sample, and the probability value indicates an 80 percent chance that the estimate is not significantly different from zero. In contrast, 17 of the 36 fixed effects in the permit equation are significant at the one percent level and another 11 are significant at the five percent level. The coefficient on the years to Phase II variable, $\phi$, reported in Table 5 is positive as expected and significant. ${ }^{11}$ A plot of the distribution of the disequilibrium terms for each firm from equation (15) appears in Figure 2. The average wedge, which represents the combination of transactions costs and uncertainty premium, across the 36 firms is 9 percent with a standard deviation of 6.1 percent. ${ }^{12}$ Joskow and Schmalensee (1998) note that the average commission per allowance trade in 1996 was less than $2 \%$ of the prevailing spot price for $\mathrm{SO}_{2}$ allowances. ${ }^{13}$ This suggests that firms on average are willing to pay a 7 percent uncertainty premium from holding pollution permits. These results

\footnotetext{
${ }^{11}$ We also included the annual average monthly standard deviation in emission prices as a measure of uncertainty. Although this variable also proved significant, the probability value on the objective function was substantially lower and this version resulted in curvature violations. In another specification, the years to Phase II variable was dropped and the objective function declined substantially and high-sulfur fuel and permit stocks were long run substitutes, which is counter-intuitive..

12 The wedge could also reflect the idiosyncratic nature of allocations although our estimator attempts to control for these effects with the regulatory policy instruments.

${ }^{13}$ Conrad and Kohn (1996) conclude that transaction costs have not significantly affected the trading and price of $\mathrm{SO}_{2}$ allowances.
} 
suggest that uncertainty and perhaps other fixed effects are relatively more important than a convenience yield from short-run variable cost savings earned from holding pollution permit stocks.

Table 6 contains the estimated short-run price elasticities of demand. The only short-run input that significantly responds to output is high sulfur fuel, which fuels the bulk of base-load power generation. Permit stocks significantly affect the demand for fuels. Higher permit stocks, for instance, shift out the demand curve for low-sulfur fuel and decrease the demand for highsulfur fuel. This finding reflects the accumulation of permit stocks and the shift from high to low sulfur fuels observed during the sample. Also, higher permit stocks increase the demand for emissions, with a probability level of 6.5 percent. The partial effects of capital are significant with higher capital stocks, ceteris paribus, significantly reducing the demand for emissions, labor, and maintenance.

Another question is whether substitution possibilities between the environment and other factors of production are any greater or less than other factor input substitutions. For this question, a unit-less measure of substitution is needed. The analysis by Blackorby and Russell (1989) proves that the Morishima elasticity is a superior measure of substitution. This is particularly important for this study because it provides a clear distinction between substitutions induced by permit prices versus other input price changes. Morishima elasticities are defined as follows:

$$
M_{i j}=\frac{\partial \ln x_{j}}{\partial \ln w_{i}}-\frac{\partial \ln x_{i}}{\partial \ln w_{i}}=\frac{-\partial \ln \left(x_{i} / x_{j}\right)}{\partial \ln w_{i}}
$$


These elasticities measure the curvature of an isoquant, or the percentage change in a factor input ratio for a given percentage change in price, holding all other factor prices constant. As the above equation illustrates, the effect of varying $w_{i}$ on the factor input ratio, $x_{i} / x_{j}$, is composed of two parts - the effect of $w_{i}$ on $x_{i}$ and the effect of $w_{i}$ on $x_{j}$. Blackorby and Russell (1989) show that these elasticities are inherently asymmetric.

The estimated short-run Morishima elasticities of substitution appear in Table 7. Ten out of the twelve substitution elasticities are significant at the five percent level. Substitutability dominates even in the short-run, when stocks of permits and capital are fixed. As expected, high-sulfur fuel and emissions are estimated complements, but the elasticity is insignificant. Across the columns of Table 7, the elasticities of factor input ratios are substantially larger for low-sulfur fuel than they are for other price changes. For instance, the ratio of high-sulfur fuel to low-sulfur fuel rises 2.57 percent for every percent increase in low sulfur fuel prices while the high sulfur fuel to emissions factor ratio responds 0.74 percent for a change in the emissions price. These finding suggest that relative fuel prices are relatively more important in factor substitution than changes in emissions prices in the short run.

The long-run elasticities allow permit and capital stocks to adjust with their respective user costs, prices for variable factors, and output. So, for example, as the price of emissions changes in the long-run, permit stocks change, which then shift the short-run demand curves. The long-run elasticities are defined as follows:

$$
\frac{\partial \ln x_{i}{ }^{L R}}{\partial \ln w_{j}}=\left.\frac{\partial \ln x_{i}}{\partial \ln w_{j}}\right|_{\bar{B}, \bar{K}}+\frac{\partial \ln x_{i}}{\partial \ln B} \frac{\partial \ln B}{\partial \ln w_{j}}+\frac{\partial \ln x_{i}}{\partial \ln K} \frac{\partial \ln K}{\partial \ln w_{j}}
$$


The second two terms in (16) measure the shift in the short-run demand curves as the product of the elasticity of the variable factor demand with respect to the quasi-fixed factor and the cross price elasticity between the quasi-fixed and variable factors. ${ }^{14}$ The long-run price elasticities are presented in Table 8. All long-run own-price elasticities of demand are negative, but only three are significant, low-sulfur fuel, wages and maintenance, and capital. The long-run demand for low-sulfur fuel is significantly affected by its own price and prices for labor and maintenance. Output is the only significant factor affecting high sulfur fuel demand in the longrun. The demand for labor and maintenance is significantly affected by its own price, prices for low-sulfur fuel and the user cost of capital. The estimated long-run demand elasticities for emissions reflect significant substitution with capital. As expected, high sulfur fuel and permit stocks are significant long-run complements. In contrast, low-sulfur fuel and permit stocks are significant long-run substitutes, also as expected. The cross elasticities of demand for capital indicate significant substitution of capital inputs in response to prices for labor and maintenance and emissions prices.

Finally, the long-run Morishima elasticities of substitution are presented in Table 9. Similar to the short-run substitution elasticities, low sulfur fuel prices significantly induce substitution among most factor input ratios, with the exception of high-sulfur fuel (see column 2 of Table 9). The price of high-sulfur fuel significantly affects the ratio of permit stocks to highsulfur fuel use. Wages and prices for maintenance also induce significant substitution for all factor inputs with the exception of permit stocks (column 4, Table 9). Emissions prices are

\footnotetext{
14 The long-run elasticities are evaluated at equilibrium levels for quasi-fixed factors, which are computed by simultaneously solving the two quasi-fixed factor demand equations, including the fixed factors.
} 
significant in prompting long-run substitution between capital and emissions. The user cost of permits does not induce significant substitution between permits and all other factor inputs in the long-run. The user cost of capital, however, significantly induces substitution between capital and fuel, labor and maintenance, and emissions. Overall, these elasticities suggest considerable substitution possibilities between environmental resources, labor, capital, and energy.

\section{Conclusions}

The $\mathrm{SO}_{2}$ trading program in the United States provides a means for society to discover prices for emissions or the price society is willing to pay for avoiding damages from the consumption of common property resources, such as the atmosphere and other environmental resources. This paper applies a neoclassical cost model to examine substitution possibilities between the environment and other factors of production. With an efficient market for pollution allowances, permit prices provide an essential signal for resource allocation. Similarly, forward prices for permits provide firms with information for allocating permits over time.

Our econometric estimates suggest considerable substitution possibilities exist between environmental emissions, fuels, labor, and capital in electric power generation. In the short run with fixed stocks of permits and capital, changes in low sulfur fuel prices have the largest impacts on factor substitution. While emissions prices are significant, relative fuel prices in the short run are a relatively more important determinant of factor substitution than changes in emission permit prices. As stocks of capital and permits adjust in the long run, relative fuel prices continue to be the predominant force inducing factor substitution.

The results also indicate the presence of an uncertainty premium that justifies holding stocks of permits even in the presence of sizeable user costs. Prices for permits induce factor 
substitution that improves the environment. Although our findings suggest a short-run positive elasticity between emissions and permit stocks, this effect is very small and insignificant. Hence, fears that a large initial allocation of permits may lead to higher emissions, which is a concern with the allocation of greenhouse gas or "hot-air" permits, may be unfounded.

\section{References}

Arimura, T.H. "An Empirical Study of the $\mathrm{SO}_{2}$ Allowance Market: Effects Of PUC Regulations," Journal of Environmental Economics and Management, 2002, 44(2), pp. 271-289. Ayres, Robert. U. and A. V. Kneese 1969, "Production, Consumption, and Externalities," American Economic Review, 1969, 59(3), pp. 282-297.

Ayres, Robert. U. Resources, Environment and Economics: Applications of the Materials/Energy Balance Principle. New York: Willey-Interscience, 1978, pp. 1-10.

Ayres, Robert. U. 1999, "The Minimum Complexity of Endogenous Growth Models: The Role of Physical Resource Flows and Technology," Working paper, INSEAD, Centre for the Management of Environmental Resources, 99/37/EPS, 1999.

Bailey, Elizabeth. "Intertemporal Pricing of Sulfur Dioxide Allowances," Working paper, Center for Energy and Environmental Policy Research, MIT, 1998, March, 1998.

Bartels, Carlton.W. 1997, "Recent Trends in the $\mathrm{SO}_{2}$ Allowance Marketplace," Working paper, New York, Cantor-Fitzgerald Environmental Brokerage Services, 1997.

Blackorby, C., and Russell, R. R. "Will the real elasticity of substitution please stand up?" The American Economic Review, 1989, 79(4), pp. 882-888.

Brealey, R.A. and S.C. Myers. Principles of Corporate Finance, New York, McGraw-Hill Irwin Inc., 2003, pp. 762-763.

Carlson, C., Dallas Burtraw, Maureen Cropper, and Karen Palmer, "Sulfur Dioxide Control by Electric Utilities: What are the Gains from Trade?" Journal of Political Economy, 2000, 108(6), pp. 1292-1326.

Caves, D. W., and Lauritis. R. Christensen. "Global Properties of Flexible Functional Forms," American Economic Review, 1980, 70(3), pp. 422-432. 
Christensen, L. R., and W. H. Greene. "Economies of Scale in U. S. Electric Power Generation," Journal of Political Economy, 1976, 84(4), pp. 655-676.

Cronshaw, M. and J. Kruse. "Regulated Firms in Pollution Permit Markets with Banking," Journal of Regulatory Economics, 1996, 9(1), 179-189.

Ellerman A.D. and Montero J.-P. "The Declining Trend in Sulfur Dioxide Emissions: Implications for Allowance Prices," The Journal of Environmental Economics and Management, 1998(1), 36, pp. 26-45.

Ellerman, A. D., Joskow, Paul. L., Schmalensee, Richard, Montero, J.P, and Bailey, Elizabeth. M. Markets for Clean Air: The U.S. Acid Rain Program, 2000, New York: Cambridge University Press.

Joskow, Paul and Schmalensee. Richard. "The Political Economy of Market-Based Environmental Policy: The U.S. Acid Rain Program,” Journal of Law and Economics, 1998, 41(1), pp. 89-135.

Keohane, N. "Environmental Policy and the Choice of Abatement Technique: Evidence from Coal-Fired Power Plants,' Harvard University, Working Paper, 2001, 44 pgs.

Kling, Catherine. and J. Rubin. "Bankable Permits for the Control of Environmental Pollution," Journal of Public Economics, 1997, 64(1), 101-115.

Lile, R. and Burtraw, Dallas. "State-Level Policies and Regulatory Guidance for Compliance in the Early Years of the SO2 Emission Allowance Trading Program," Resources for the Future, Discussion Paper, 1998, 35, 52 pages.

Morrison, Catherine. 1988, "Quasi-fixed Inputs in U. S. and Japanese Manufacturing: A Generalized Leontief Restricted Cost Function Approach, ” The Review of Economics and Statistics, 1988, 70(2), pp. 275-287.

Ramey, Valerie A. "Inventories as Factors of Production and Economic Fluctuations," American Economic Review, 1989, 79(3), pp. 338-354.

Rubin, J. “A Model of Intertemporal Emissions Trading, Banking, and Borrowing," Journal of Environmental Economics and Management, 1996, 31(3), pp. 269-286.

Rubin. J. and C. Kling. "An Emission Saved is an Emission Earned: An Empirical Study of Emissions Banking for Light-duty Vehicle Manufacturers," Journal of Environmental Economics and Management, 1993, 25(3), pp. 257-274. 
Shea, John. "The Input-Output Approach to Instrumental Selection," Journal of Business and Economic Statistics, 1993, 11(1), pp. 145-155.

Schennach, S. "The economics of Pollution Permit Banking in the Context of Title IV of the 1990 Clean Air Act Amendments," Journal of Environmental Economics and Management, 2000, 40(3), pp. 189-210.

Schmalensee, Richard, Paul Joskow, A. Ellerman, J. Montero, and Elizabeth Bailey 1998, “An Interim Evaluation of Sulfur Dioxide Emissions Trading,' Journal of Economic Perspectives, 1998, 12(1), pp. 53-68.

Stavins, Robert N. "Transaction Costs and Tradable Permits”, Journal of Environmental Economics and Management, 1995, 29(2), pp. 133-148.

Tietenberg, Thomas. H. "Economic Instruments for Environmental Regulation," Oxford Review of Economic Policy, 1990, 6(1), pp. 17-33.

van den Bergh, J. C. J. M. "Materials, Capital, Direct/Indirect Substitution, and Mass Balance Production Functions," Land Economics, 1999, 75(4), pp. 547-561. 
Table 1: Permit allowances held in various accounts in thousands, 1996-2001

\begin{tabular}{llllllll}
\hline & $1996^{\mathrm{a}}$ & 1997 & 1998 & 1999 & 2000 & 2001 & 2002 \\
\hline Table A & 6,900 & 6,888 & 5,822 & 5,729 & 5,723 & 9,584 & 9,191 \\
Sub. \& Com. & 1,329 & 1,175 & 1,040 & 965 & 995 & 11 & 14 \\
Opt-in & 314 & 48 & 96 & 98 & 97 & 98 & 99 \\
Diesel \& Conservation & 50 & 35 & 39 & 28 & 26 & 34 & 4 \\
Auctions & 150 & 150 & 150 & 150 & 150 & 250 & 250 \\
Total Held & 8,744 & 11,732 & 13,427 & 14,925 & 16,618 & 21,584 & 19,939 \\
Emissions & & 5,453 & 5,480 & 5,301 & 4,948 & 11,202 & 10,633 \\
Banked & 3,436 & 6,279 & 7,956 & 9,628 & 11,608 & 10,382 & 9,306 \\
Allocations & 6,937 & 8,121 & 6,958 & 6,884 & 6,841 & 9,725 & 9,320 \\
\multicolumn{7}{l}{ a. Jan 30 } \\
Source: EPA, SO2 Compliance Reports.
\end{tabular}

Table 2: Summary statistics for output and input costs per unit of output, 1995-1999

\begin{tabular}{lcccc}
\hline & Mean & $\begin{array}{c}\text { Standard } \\
\text { Deviation }\end{array}$ & Minimum & Maximum \\
\hline Output (million Mwh) & 22.38 & 24.97 & 2.23 & 123.47 \\
& \multicolumn{4}{c}{ Cents per kilowatt hour } \\
Fuel cost & 1.50 & 0.40 & 0.91 & 3.32 \\
$\quad$ Low sulfur fuel & 0.33 & 0.45 & 0.01 & 2.51 \\
$\quad 1.17$ & 0.43 & 0.05 & 2.12 \\
$\quad$ High sulfur fuel & 0.52 & 0.19 & 0.28 & 1.22 \\
Labor \& maintenance & 0.07 & 0.06 & 0.01 & 0.39 \\
Emissions & 2.08 & 0.50 & 1.31 & 3.89 \\
Short-run variable cost & 0.04 & 0.05 & 0.00 & 0.31 \\
Permit costs & 0.89 & 0.30 & 0.38 & 1.98 \\
Capital costs & 3.00 & 0.66 & 2.04 & 5.59 \\
Total costs & & &
\end{tabular}

Table 3: Summary statistics for permit balances in thousand tons

\begin{tabular}{|c|c|c|c|c|}
\hline & Mean & Standard Deviation & Minimum & Maximum \\
\hline \multicolumn{5}{|l|}{ Stocks } \\
\hline & 79.2 & 168.8 & 0.4 & 1454.6 \\
\hline Allocations & 167.2 & 218.2 & 9.4 & 1170.3 \\
\hline Net purchases & -20.4 & 73.2 & -343.1 & 163.4 \\
\hline Emissions & 126.6 & 157.4 & 2.7 & 712.0 \\
\hline
\end{tabular}


Table 4: Summary fit statistics

\begin{tabular}{lccc}
\hline \multicolumn{1}{c}{ Equation } & $\mathrm{R}^{2}$ & $\begin{array}{c}\text { Durbin } \\
\text { Watson }\end{array}$ & $\begin{array}{c}\text { Probability } \\
\text { value }\end{array}$ \\
\hline High sulfur fuel & 0.94 & 1.70 & 0.99 \\
Low sulfur fuel & 0.95 & 1.40 & 0.60 \\
Labor \& maintenance & 0.95 & 1.45 & 0.72 \\
Emissions & 0.96 & 1.09 & 0.01 \\
Permit stocks & 0.45 & 2.31 & 1.00 \\
Capital stocks & 0.86 & 1.57 & 0.94 \\
\hline
\end{tabular}


Table 5: Parameter estimates from generalized method of moments estimation

\begin{tabular}{lcccc}
\hline & & Standard & & Probability \\
$\alpha_{12}$ & 0.6955 & 0.157 & 4.418 & {$[.000]$} \\
$\alpha_{13}$ & 0.4607 & 0.085 & 5.425 & {$[.000]$} \\
$\alpha_{14}$ & 0.0365 & 0.038 & 0.969 & {$[.333]$} \\
$\delta_{1 y}$ & -0.1277 & 0.059 & -2.175 & {$[.030]$} \\
$\gamma_{y y}$ & -0.0020 & 0.001 & -1.485 & {$[.138]$} \\
$\delta_{k 1}$ & -0.0484 & 0.069 & -0.702 & {$[.483]$} \\
$\delta_{a 1}$ & 1.5930 & 0.955 & 1.668 & {$[.095]$} \\
$\gamma_{y k}$ & -0.0060 & 0.003 & -1.756 & {$[.079]$} \\
$\gamma_{y a}$ & 0.0532 & 0.029 & 1.829 & {$[.067]$} \\
$\gamma_{k k}$ & 0.0081 & 0.006 & 1.348 & {$[.178]$} \\
$\gamma_{k a}$ & -0.0093 & 0.042 & -0.222 & {$[.824]$} \\
$\gamma_{a a}$ & -0.9868 & 1.766 & -0.559 & {$[.576]$} \\
$\alpha_{23}$ & 0.1358 & 0.118 & 1.152 & {$[.249]$} \\
$\alpha_{24}$ & -0.0643 & 0.039 & -1.633 & {$[.103]$} \\
$\delta_{y 2}$ & 0.1449 & 0.068 & 2.120 & {$[.034]$} \\
$\delta_{k 2}$ & 0.0881 & 0.076 & 1.160 & {$[.246]$} \\
$\delta_{a 2}$ & -2.7030 & 0.902 & -2.996 & {$[.003]$} \\
$\alpha_{34}$ & 0.0394 & 0.019 & 2.076 & {$[.038]$} \\
$\delta_{y 3}$ & -0.2131 & 0.038 & -5.636 & {$[.000]$} \\
$\delta_{k 3}$ & -0.1463 & 0.044 & -3.338 & {$[.001]$} \\
$\delta_{a 3}$ & 0.1974 & 0.453 & 0.436 & {$[.663]$} \\
$\delta_{y 4}$ & 0.0044 & 0.024 & 0.186 & {$[.853]$} \\
$\delta_{k 4}$ & -0.0490 & 0.035 & -1.393 & {$[.164]$} \\
$\delta_{a 4}$ & 0.1812 & 0.234 & 0.773 & {$[.439]$} \\
$\phi$ & 3.6320 & 0.726 & 5.000 & {$[.000]$} \\
\hline & & & &
\end{tabular}


Table 6: Short-run input demand elasticities with absolute t-statistics in parentheses

\begin{tabular}{|c|c|c|c|c|c|c|c|}
\hline & $\begin{array}{l}\text { Low sulfur } \\
\text { fuel price }\end{array}$ & $\begin{array}{l}\text { High sulfur } \\
\text { fuel price }\end{array}$ & $\begin{array}{c}\text { Wages \& } \\
\text { Maint. prices }\end{array}$ & $\begin{array}{c}\text { Emissions } \\
\text { price }\end{array}$ & $\begin{array}{l}\text { Stock of } \\
\text { permits }\end{array}$ & $\begin{array}{c}\text { Stock of } \\
\text { capital }\end{array}$ & Output \\
\hline Low sulfur fuel & $\begin{array}{c}-2.29 \\
(6.1)\end{array}$ & $\begin{array}{l}1.31 \\
(4.4)\end{array}$ & $\begin{array}{l}0.91 \\
(5.4)\end{array}$ & $\begin{array}{l}0.07 \\
(1.0)\end{array}$ & $\begin{array}{l}0.19 \\
(1.8)\end{array}$ & $\begin{array}{l}-0.18 \\
(0.7)\end{array}$ & $\begin{array}{l}-0.46 \\
(0.3)\end{array}$ \\
\hline High sulfur fuel & $\begin{array}{l}0.28 \\
(4.4)\end{array}$ & $\begin{array}{l}-0.31 \\
(4.8)\end{array}$ & $\begin{array}{l}0.05 \\
(1.1)\end{array}$ & $\begin{array}{l}-0.03 \\
(1.6)\end{array}$ & $\begin{array}{l}-0.06 \\
(2.9)\end{array}$ & $\begin{array}{l}0.09 \\
(1.3)\end{array}$ & $\begin{array}{l}1.17 \\
(3.0)\end{array}$ \\
\hline $\begin{array}{l}\text { Labor \& } \\
\text { maintenance }\end{array}$ & $\begin{array}{l}0.50 \\
(5.4)\end{array}$ & $\begin{array}{l}0.14 \\
(1.1)\end{array}$ & $\begin{array}{l}-0.68 \\
(5.9)\end{array}$ & $\begin{array}{l}0.04 \\
(2.1)\end{array}$ & $\begin{array}{l}0.02 \\
(0.5)\end{array}$ & $\begin{array}{l}-0.35 \\
(3.5)\end{array}$ & $\begin{array}{l}-0.05 \\
(0.07)\end{array}$ \\
\hline Emissions & $\begin{array}{l}0.25 \\
(1.0)\end{array}$ & $\begin{array}{l}-0.43 \\
(1.6)\end{array}$ & $\begin{array}{l}0.28 \\
(2.1)\end{array}$ & $\begin{array}{l}-0.09 \\
(2.4)\end{array}$ & $\begin{array}{c}0.11 \\
(1.8)\end{array}$ & $\begin{array}{c}-0.65 \\
(4.2)\end{array}$ & $\begin{array}{l}0.67 \\
(0.4)\end{array}$ \\
\hline
\end{tabular}

Table 7: Short-run Morishima elasticities with absolute t-statistics in parentheses

\begin{tabular}{lcccc}
\hline & $\begin{array}{c}\text { Low sulfur } \\
\text { fuel price }\end{array}$ & $\begin{array}{c}\text { High sulfur } \\
\text { fuel price }\end{array}$ & $\begin{array}{c}\text { Wages \& } \\
\text { Maintenance } \\
\text { price }\end{array}$ & $\begin{array}{c}\text { Emissions } \\
\text { price }\end{array}$ \\
\hline Low sulfur fuel & & 1.62 & 1.59 & 0.17 \\
& & $(4.7)$ & $(7.1)$ & $(2.1)$ \\
High sulfur fuel & 2.57 & & 0.74 & 0.07 \\
& $(5.9)$ & & $(4.8)$ & $(1.5)$ \\
Labor \& & 2.79 & 0.45 & & 0.14 \\
maintenance & $(6.4)$ & $(2.9)$ & & $(2.8)$ \\
Emissions & 2.54 & -0.12 & 0.96 & \\
& $(5.3)$ & $(0.4)$ & $(4.4)$ & \\
\hline
\end{tabular}


Table 8: Long-run input demand elasticities with absolute t-statistics in parentheses

\begin{tabular}{|c|c|c|c|c|c|c|c|}
\hline & $\begin{array}{l}\text { Low sulfur } \\
\text { fuel price }\end{array}$ & $\begin{array}{l}\text { High sulfur } \\
\text { fuel price }\end{array}$ & $\begin{array}{c}\text { Wages \& } \\
\text { Maintenance } \\
\text { price }\end{array}$ & $\begin{array}{c}\text { Emissions } \\
\text { price }\end{array}$ & $\begin{array}{l}\text { User cost } \\
\text { for permits }\end{array}$ & $\begin{array}{l}\text { User cost } \\
\text { of capital }\end{array}$ & Output \\
\hline Low sulfur fuel & $\begin{array}{l}-1.45 \\
(2.0)\end{array}$ & $\begin{array}{l}0.44 \\
(0.7)\end{array}$ & $\begin{array}{l}0.77 \\
(2.0)\end{array}$ & $\begin{array}{l}0.15 \\
(0.6)\end{array}$ & $\begin{array}{c}-0.03 \\
(0.5)\end{array}$ & $\begin{array}{l}0.13 \\
(0.4)\end{array}$ & $\begin{array}{l}-0.25 \\
(0.2)\end{array}$ \\
\hline High sulfur fuel & $\begin{array}{l}0.09 \\
(0.5)\end{array}$ & $\begin{array}{l}-0.07 \\
(0.4)\end{array}$ & $\begin{array}{l}0.05 \\
(0.3)\end{array}$ & $\begin{array}{l}-0.07 \\
(0.8)\end{array}$ & $\begin{array}{l}0.01 \\
(0.6)\end{array}$ & $\begin{array}{l}-0.02 \\
(0.2)\end{array}$ & $\begin{array}{l}1.23 \\
(3.0)\end{array}$ \\
\hline $\begin{array}{l}\text { Labor \& } \\
\text { maintenance }\end{array}$ & $\begin{array}{l}0.32 \\
(2.3)\end{array}$ & $\begin{array}{l}0.14 \\
(1.1)\end{array}$ & $\begin{array}{l}-0.76 \\
(4.0)\end{array}$ & $\begin{array}{l}-0.06 \\
(1.2)\end{array}$ & $\begin{array}{l}-0.01 \\
(0.2)\end{array}$ & $\begin{array}{l}0.36 \\
(2.5)\end{array}$ & $\begin{array}{l}-0.10 \\
(0.2)\end{array}$ \\
\hline Emissions & $\begin{array}{l}0.22 \\
(0.7)\end{array}$ & $\begin{array}{l}-0.35 \\
(1.2)\end{array}$ & $\begin{array}{l}-0.27 \\
(1.0)\end{array}$ & $\begin{array}{l}-0.17 \\
(1.0)\end{array}$ & $\begin{array}{l}-0.01 \\
(0.5)\end{array}$ & $\begin{array}{l}0.59 \\
(2.1)\end{array}$ & $\begin{array}{l}0.38 \\
(0.4)\end{array}$ \\
\hline Permit stocks & $\begin{array}{l}7.91 \\
(1.6)\end{array}$ & $\begin{array}{l}-9.54 \\
(2.7)\end{array}$ & $\begin{array}{l}2.26 \\
(0.9)\end{array}$ & $\begin{array}{l}2.02 \\
(1.1)\end{array}$ & $\begin{array}{l}-2.32 \\
(0.7)\end{array}$ & $\begin{array}{l}-0.34 \\
(0.6)\end{array}$ & $\begin{array}{l}3.14 \\
(1.0)\end{array}$ \\
\hline Capital stocks & $\begin{array}{l}1.12 \\
(1.1)\end{array}$ & $\begin{array}{l}-1.20 \\
(1.1)\end{array}$ & $\begin{array}{l}2.72 \\
(2.3)\end{array}$ & $\begin{array}{c}1.07 \\
(2.25)\end{array}$ & $\begin{array}{l}-0.01 \\
(0.0)\end{array}$ & $\begin{array}{l}-3.67 \\
(2.6)\end{array}$ & $\begin{array}{l}3.23 \\
(2.4)\end{array}$ \\
\hline
\end{tabular}

Table 9: Long-run Morishima elasticities with absolute t-statistics in parentheses

\begin{tabular}{|c|c|c|c|c|c|c|}
\hline & $\begin{array}{l}\text { Low sulfur } \\
\text { fuel price }\end{array}$ & $\begin{array}{l}\text { High sulfur } \\
\text { fuel price }\end{array}$ & $\begin{array}{c}\text { Wages \& } \\
\text { Maintenance } \\
\text { prices }\end{array}$ & $\begin{array}{c}\text { Emissions } \\
\text { price }\end{array}$ & $\begin{array}{l}\text { User cost } \\
\text { for permits }\end{array}$ & $\begin{array}{l}\text { User cost } \\
\text { of capital }\end{array}$ \\
\hline Low sulfur fuel & & $\begin{array}{l}0.51 \\
(0.6)\end{array}$ & $\begin{array}{l}1.53 \\
(3.6)\end{array}$ & $\begin{array}{l}0.32 \\
(1.7)\end{array}$ & $\begin{array}{l}0.31 \\
(0.7)\end{array}$ & $\begin{array}{l}3.89 \\
(2.6)\end{array}$ \\
\hline High sulfur fuel & $\begin{array}{l}1.54 \\
(1.7)\end{array}$ & & $\begin{array}{l}0.81 \\
(3.2)\end{array}$ & $\begin{array}{c}0.10 \\
(0.48)\end{array}$ & $\begin{array}{l}0.35 \\
(0.7)\end{array}$ & $\begin{array}{l}3.75 \\
(2.5)\end{array}$ \\
\hline $\begin{array}{l}\text { Labor \& } \\
\text { maintenance }\end{array}$ & $\begin{array}{l}1.77 \\
(2.5)\end{array}$ & $\begin{array}{l}0.21 \\
(0.9)\end{array}$ & & $\begin{array}{c}0.11 \\
(0.85)\end{array}$ & $\begin{array}{l}0.34 \\
(0.6)\end{array}$ & $\begin{array}{l}4.13 \\
(2.6)\end{array}$ \\
\hline Emissions & $\begin{array}{l}1.67 \\
(2.6)\end{array}$ & $\begin{array}{l}-0.28 \\
(0.7)\end{array}$ & $\begin{array}{l}0.69 \\
(3.0)\end{array}$ & & $\begin{array}{c}0.33 \\
(0.7)\end{array}$ & $\begin{array}{l}4.35 \\
(2.6)\end{array}$ \\
\hline Permit stocks & $\begin{array}{l}9.37 \\
(2.3)\end{array}$ & $\begin{array}{l}-9.46 \\
(2.6)\end{array}$ & $\begin{array}{l}3.02 \\
(1.2)\end{array}$ & $\begin{array}{l}2.19 \\
(1.2)\end{array}$ & & $\begin{array}{l}1.47 \\
(0.5)\end{array}$ \\
\hline Capital stocks & $\begin{array}{l}2.57 \\
(2.0)\end{array}$ & $\begin{array}{l}-1.12 \\
(1.0)\end{array}$ & $\begin{array}{l}3.53 \\
(2.6)\end{array}$ & $\begin{array}{l}1.24 \\
(2.0)\end{array}$ & $\begin{array}{l}0.34 \\
(0.6)\end{array}$ & \\
\hline
\end{tabular}


Figure 1: Spot and Forward Price Spreads for $\mathrm{SO}_{2}$ pollution permits, 1995-2001

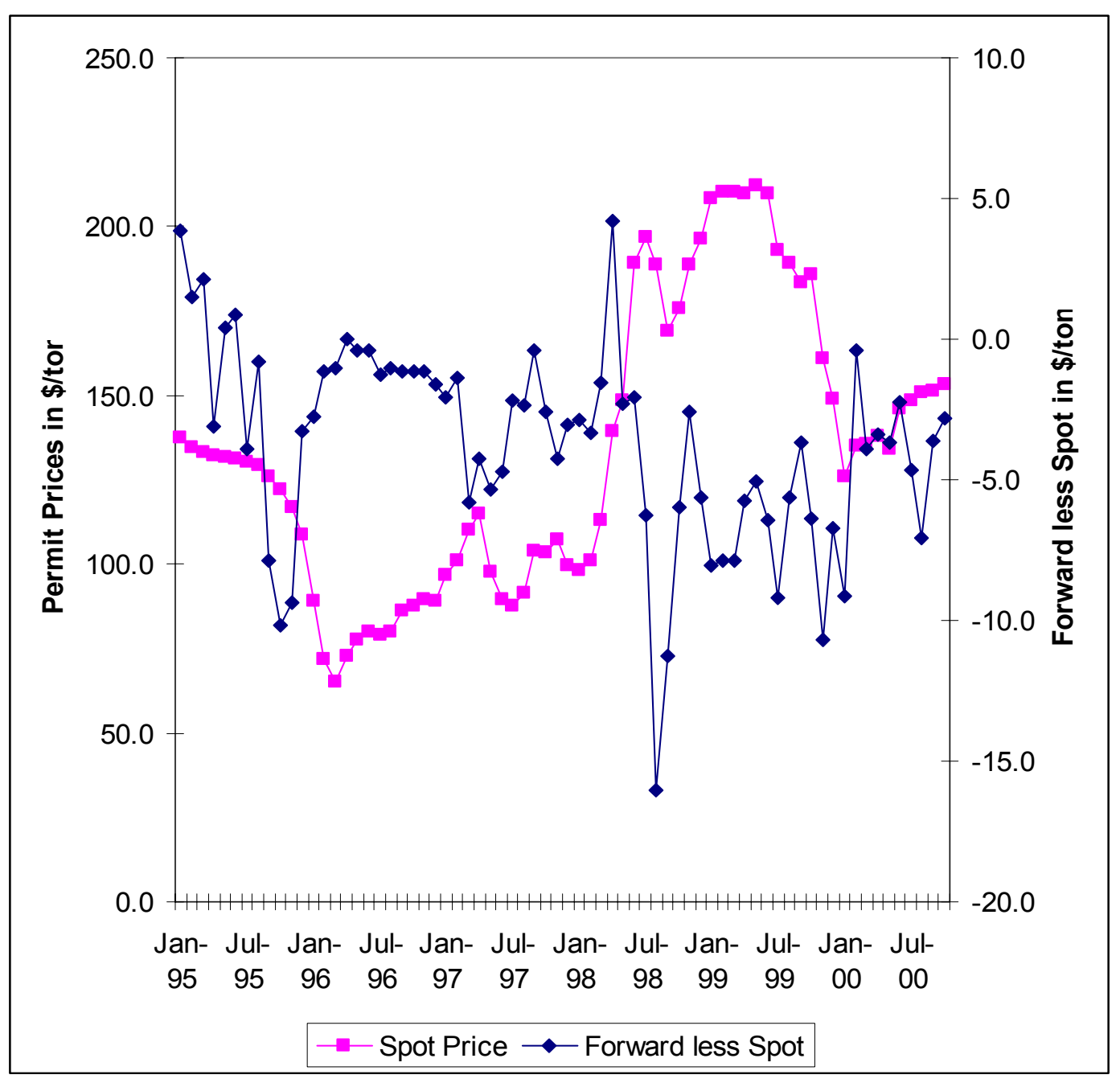


Figure 2: Distribution of transactions costs and uncertainty premiums for pollution permit stock holding

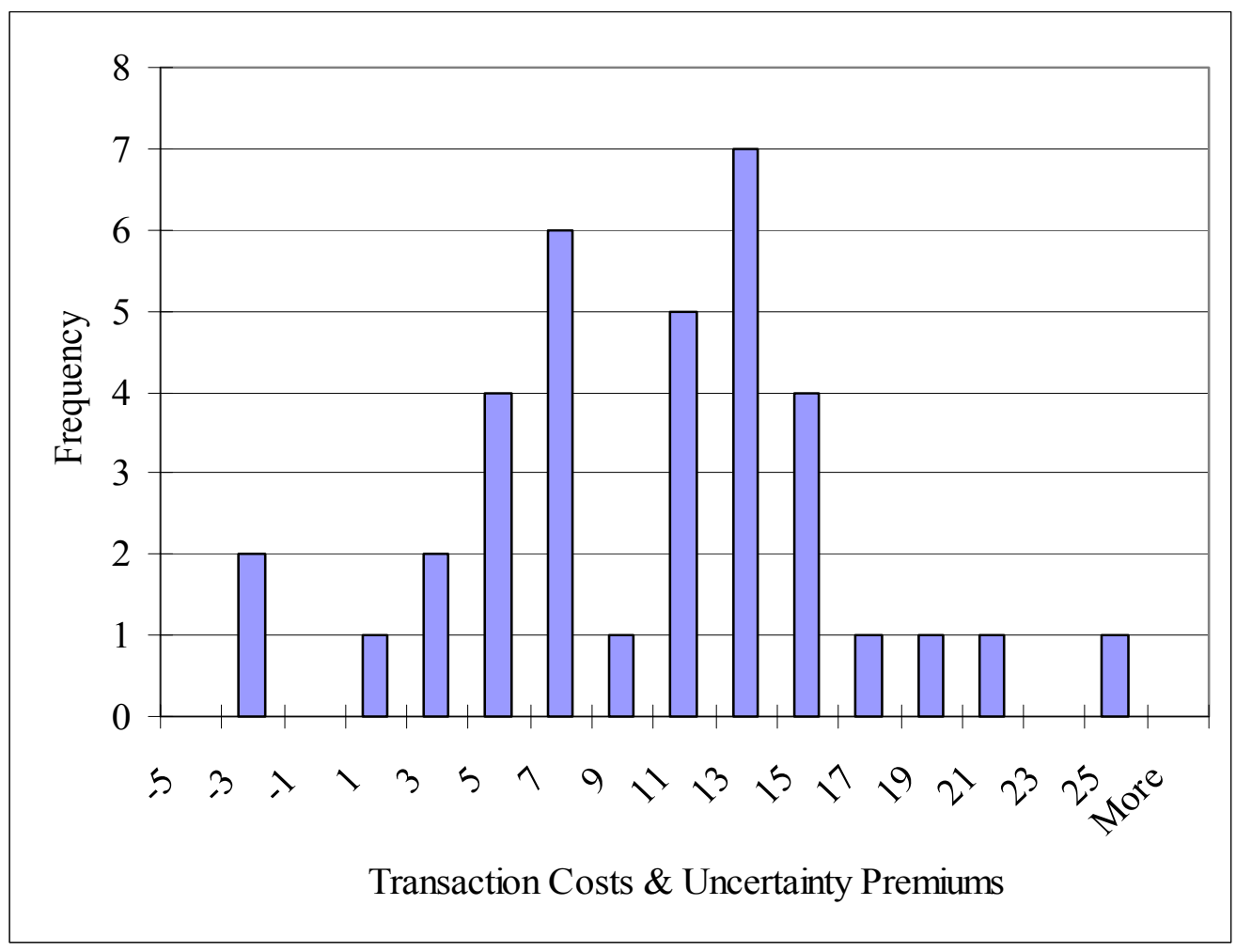




\section{Appendix A}

\begin{tabular}{|c|c|}
\hline Holding Company / Member & Holding Company / Member \\
\hline Allegheny Power Systems Inc. & Commonwealth Edison $\mathrm{Co}^{*}$ \\
\hline Monongahela Power Co & Consumers Power Co \\
\hline Potomac Edison Co & Dayton Power \& Light Co \\
\hline West Penn Power Co & Duquesne Light Co \\
\hline American Electric Power Company Inc & Indianapolis Power \& Light Co \\
\hline Appalachian Power Co & Kentucky Utilities Co \\
\hline Columbus Southern Power Co & Northern Indiana Pub Serv Co \\
\hline Indiana Michigan Power Co & Ohio Edison Co. \\
\hline Kentucky Power Co & Ohio Edison Co \\
\hline Ohio Power Co & Pennsylvania Power Co \\
\hline CINergy Corporation & Ohio Valley Electric Corp \\
\hline Cincinnati Gas \& Electric Co & PSI Energy Inc \\
\hline General Public Utilities Corporation* & Tampa Electric Co \\
\hline Jersey Central Power \& Light C & Virginia Electric \& Power Co \\
\hline Metropolitan Edison Co & Wisconsin Electric Power Co \\
\hline Pennsylvania Electric Co & Wisconsin Power \& Light Co \\
\hline The Southern Company & Baltimore Gas \& Electric Co \\
\hline Alabama Power Co & Central Hudson Gas \& Elec Corp* \\
\hline Georgia Power Co & Illinois Power $\mathrm{Co}^{*}$ \\
\hline Gulf Power Co & Interstate Power Co \\
\hline Mississippi Power Co & Kansas City Power \& Light Co \\
\hline Savannah Electric \& Power Co & Long Island Lighting $\mathrm{Co}^{* *}$ \\
\hline Atlantic City Electric Co & New York State Elec \& Gas Corp** \\
\hline Niagara Mohawk Power Corp* & Pennsylvania Power \& Light Co \\
\hline Central Illinois Pub Serv Co & Potomac Electric Power Co \\
\hline Centerior Energy Corp. & Southern Indiana Gas \& Elec Co \\
\hline Cleveland Electric Illum Co & Union Electric Co \\
\hline Toledo Edison Co & UtiliCorp United Inc \\
\hline Empire District Electric Co & Wisconsin Public Service Co \\
\hline $\begin{array}{l}\text { * } 1999 \text { removed, } \\
\text { ** } 1998 \text { \& } 1999 \text { observations remov }\end{array}$ & \\
\hline
\end{tabular}

